\title{
Proverbs 31:10-31: A passage containing wisdom principles for a successful marriage
}

\section{Author: \\ Robin Gallaher Branch ${ }^{1,2}$ \\ Affiliations: \\ ${ }^{1}$ Faculty of Theology, North- \\ West University, South Africa \\ ${ }^{2}$ Department of Bible and Theology, Victory University,} United States of America

\section{Correspondence to:}

Robin Gallaher Branch

Email:

rgbranch@victory.edu

\section{Postal address:}

Department of Bible and

Theology, Victory University,

255 North Highland,

Memphis, TN 38111

United States of America

\section{Dates:}

Received: 08 June 2011

Accepted: 20 June 2012

Published: 14 Dec. 2012

How to cite this article: Branch Gallaher, R., 'Proverbs 31:10-31: 'A passage containing wisdom principles for a successful marriage', Koers - Bulletin for Christian Scholarship 77(2), Art. \#49, 9 pages. http://dx.doi.org/ 10.4102/koers.v77i2.49

\section{Note:}

An earlier, shorter version of this article appeared in Afrikaans in Die Kerkblad, the church magazine of the GKSA (Gereformeerde Kerke in Suid-Afrika [the Reformed Church in South Africa]) (see Branch 2003:20-22). A version of this article was presented as a paper, 'Proverbs 31:10-31: A Biblical Model for a Successful Marriage,' at the 2008 International Congress of the Society of Biblical Literature held at the University of Auckland in Auckland, New Zealand, in July 2008 (see Branch, 'Proverbs 31' 2008). This article incorporates suggestions and insights given by the audience after the paper's presentation.

C 2012. The Authors. Licensee: AOSIS OpenJournals. This work is licensed under the Creative Commons Attribution License.
Most commentators see Proverbs 31:10-31 as an acrostic poem about an ideal wife. True, the passage presents an exemplary woman, a paragon of industry and excellence. However, this article looks at this passage in a new way: it assert that the poem depicts an excellent, successful, working marriage. The passage contains principles contained in Wisdom Literature that apply to success in any relationship - especially the most intimate one of all. A careful reading of Proverbs' concluding poem provides a glimpse, via the specific details it shares, of a healthy, happy, ongoing, stable marriage as observed over a span of time.

Spreuke 31:10-31: 'n Gedeelte met wysheidsbeginsels vir 'n suksesvolle huwelik. Die meeste Skrifverklaarders beskou Spreuke 31:10-31 as 'n lettervers oor die ideale vrou. Hierdie gedeelte beeld inderdaad 'n voorbeeldige vrou uit wat 'n toonbeeld van werkywer en uitnemendheid is. Hierdie artikel kyk egter met nuwe oë na die gedeelte en voer aan dat dit 'n voortreflike, suksesvolle en effektiewe huwelik uitbeeld. Die gedeelte bevat beginsels wat in die Wysheidsliteratuur vervat is en wat op enige suksesvolle verhouding toegepas kan word, veral op die mees intieme verhouding. 'n Noukeurige bestudering van die spesifieke besonderhede van hierdie gedeelte in Spreuke bie 'n blik op 'n gesonde, gelukkige, volgehoue en stabiele huwelik soos dit oor 'n tydperk waargeneem is.

\section{Introduction}

Commentators frequently call the conclusion of the book of Proverbs, Proverbs 31:10-31, the Bible's poem about the ideal wife. ${ }^{1}$ However, this article finds that description limiting and sees the passage as containing much more. ${ }^{2}$ For example, the passage presents principles of Wisdom Literature (like hard work and wise words) in action. In addition, the poem can be seen as offering insights on a practical personification of wisdom ${ }^{3}$ and as instruction. ${ }^{4}$ Furthermore, traditional Jewish scholarship sees the poem in three ways: as representing Jewish womanhood as a whole, as a paradigm of a wife who is truly her husband's helper (Gn 2:18-25) and as a very complex symbol of wisdom, Torah, the soul, the Sabbath and especially the Divine Presence (Apple 2011:179).

However, I see the poem as one about a real woman and not an idealised one. ${ }^{5}$ The poem provides specific examples of themes or principles expressed throughout Wisdom Literature. ${ }^{6}$ Consistent with Old Testament poetry, the passage paints a word picture (Duvall \& Hays 2012:380). Whilst reading the poem, some modern readers may wonder, 'Where is the husband and what does he do whilst this admirable (and probably exhausted!) woman works?' (see Farmer 1991:125). This article answers these questions by looking at the poem in a new way and finding out that it says quite a bit about the husband.

I believe the passage can also be read as containing principles from Proverbs that, when put into practice over the long term, lead to a successful marriage. ${ }^{7}$ Wisdom for doing well in life is both

1.Murphy (1998:245) sees the poem as an idealised portrait of a wise wife working in an ideal household and living in an ideal society. Camp (1985) also sees the poem as showing an ideal wife.

2.Davis (2009:276) uses even stronger language and finds an appositive like 'ideal wife' 'woefully inadequate'.

3.Emphasising the woman's financial management skill, Yoder (2003:427) calls her a woman of substance (Hebrew hayil) who exhibits virtues like strength, loyalty and bravery.

4.Crook (1954:137-149) argues that the poem originally instructed young girls. McCreesh (1985:25-46) views the poem as pointing to a description of Wisdom.

5.In this line of thinking, I follow Fox (2009) in his new commentary on Proverbs 10-31; see especially pages 900-916. I found an ally in a recently published political biography. Roberts (2004), writing about the wives and mothers of the men called the Founding Fathers of America, likewise follows the same line of thinking - that of seeing ordinary women live extraordinary lives and have remarkable influence.

6.This article references numerous verses in Proverbs because its core passage comes from that book, but it also quotes Song of Songs, Job and Ecclesiastes.

7.J.P. and S.C. Ives (2001:20) provide a good definition for marriage that applies to Proverbs 31:10-31 and is used as the definition for marriage for this article: 'Marriage is meant to be a monogamous, lifelong union based on love and fidelity' (italics theirs). 
accessible and available (Bakon 2008:225). The poem provides a glimpse into a happy, productive, successful union of two people and illustrates how this flexible, working marriage spills over in blessing and well-being to children, household servants and the larger community. Providing a glimpse into or a vignette concerning a marriage is not unusual in scripture. ${ }^{8}$

Proverbs may have been written as instruction for a young son (1:8), ${ }^{9}$ and in its concluding poem (31:10ff), a young man finds an exemplary wife. Employing both exegetical and psychological insights, this article argues that Proverbs 31:10-31 both concentrates on the attributes of a remarkable woman and presents a picture of a remarkable (and achievable!) marriage. Reading the text in this way is consistent with the themes and goals of the book of Proverbs. The glimpse into this marriage that the poem invites employs imagination. ${ }^{10}$ Indeed, the daily tasks the woman undertakes may be the most important work within Proverbs, for they mirror the creative actions of God (see Goettler 2009:290).

\section{General observations about the book of Proverbs}

The book of Proverbs, part of the genre called Wisdom Literature, presents two broad alternatives to life: the way of righteousness and the way of unrighteousness, the way offered by Lady Wisdom and the way advocated by her opposite, Lady Folly (see Branch 2006). Many parts of the book are didactic: Someone of import teaches, and someone of lesser import in years and experience listens and - it is hoped! - learns. ${ }^{11}$

The concept of the fear of the Lord as the beginning of wisdom brackets the book (1:7; 31:30). Proverbs starts with a father and mother instructing their son (1:8) and ends with a glimpse into the life of partners in a happy, working, ongoing, stable and prosperous marriage (31:10-31). ${ }^{12}$

In between the verses forming the book's inclusion (1:7; 31:30), Proverbs presents life's choices via stereotypes easily seen in the marketplace. The sluggard, gossip, fool, wise woman, foolish woman, nag, king, teacher, deceitful man, drunkard,

8.Consider these examples of marriages in the biblical text:

Abram and Sarai; Abraham and Sarah: Genesis 12-23

Isaac or Rebekah: Genesis 24-28

Jacob, Leah, Rachel, Bilhah, Zilpah Genesis 29-35

Potiphar and Mrs Potiphar: Genesis 39

Ruth and Boaz: The book of Ruth provides insights on their courtship

Ruth and Boaz: The book of Ruth provid
David and Michal: 2 Samuel 6:16-23

David and Michal: 2 Samuel 6:16-23

Ahab and Jezebel: 1 Kings 16:20-34; 17-21
Jeroboam I and his wife: 1 Kings 14 (see Branch 2009:83-107)

Priscilla and Aquila: Acts 18; Romans 16:3; 1 Corinthians 26:29; 2 Timothy 4:19.

9.In addition to pointing this out, Garrett (1993:248) believes the poem's purpose was to instruct these young men on the kind of wife they should look for. See also Miller (2004:26).

10.Davis (2009:264) is also one seeking to probe 'Proverbs with imagination and depth' (italics added). In discussing personification and how it invites imagination, Waltke (1988:4-5) observes that hokma is a feminine noun; consequently the Proverbs poet personifies wisdom as a lady.

11.Actually, the tone is exhortatory, Smith (2002:320) writes.

12.Garrett notes that a young man finds wisdom in three specific relationships as outlined in Proverbs. A young man must fear the Lord, heed his parents and find a good wife. Both the fear of the Lord and finding a good wife are gifts from the Lord (Eph 2:8-9; Pr 15:4; Garrett 1993:252). adulteress, foreign woman, violent man, simple youth and concerned parents are amongst those crossing its pages (see Branch 2006).

Via these stereotypes, Proverbs provides broad, general observations about life. It treats a wide range of topics and interests (Smith 2002:319). The book strongly advocates choosing wise relationships (Garrett 1993:252). The book offers the principle that wisdom can not only be taught but can also be caught and found; clearly, wisdom is available to all who want to learn (see also James 1:5). Wisdom, however, must be pursued throughout life. The book is a set of principles offering guidelines on practical choices that, in all probability, will bring about -when put in practice over a period of years - a successful life. A theme throughout the book is that a person's well-being directly relates to the choices he or she makes. Two of life's most important choices are one's marriage partner and then how one lives happily and blessedly within the marriage. Proverbs 31:10-31 addresses these choices. Arguably, for a man, the ability to choose an exemplary wife and the ability to have a happy marriage are the highlights of a life well lived. The tone of the poem, however, contains a sense of wonder, a theme throughout Proverbs - wonder at the result of wise choices and wonder at the wonderful wisdom inherent in practicing the fear of the Lord $(1: 7 ; 30: 18-19 ; 31: 30) .{ }^{13}$

Proverbs presents ways to achieve prosperity and success by focusing on the practicalities of life (Smith 2002:319). It seeks to form positive habits. It offers practical principles for a stable, happy life. Significantly, its principles are proven to be workable, wise and achievable. Indeed, the book of Proverbs pushes a program for success in life. Lady Wisdom, a teacher to the core, virtually shouts her open-enrolment, no-prerequisites-necessary academic program $(\operatorname{Pr} 8,9)$.

\section{The chapter's structure}

Proverbs 31 begins with a sharp rebuke to a young king (vv. 1-9; Yoder 2009:263) $)^{14}$ and ends with a description of an extremely practical and capable wife (vv. 10-31) (Whybray 1990:111). Both passages engage a reader's and hearer's participation, inviting them to listen to a scolding of young Lemuel by his queenly mother and then inviting them into the home life of a family in the land.

Clues to the meaning and focus of the text in question (31:10-31) are found in its structure. Firstly, it is an acrostic poem in 22 verses: The first letter of each verse begins with a consecutive letter of the Hebrew alphabet. ${ }^{15}$ Theoretically,

13.Brown (2011:36). Tone, the overall sense of a writer's intent, is an element of literature (see Lostracco \& Wilkerson 2008:iii-vi). Other elements are central idea, character, conflict, point of view, setting and language.

14.I like Yoder's visualisation of a queen mother sharply rebuking her son. Yoder (2009:263) sees the queen mother as reprimanding him sternly by saying 'What (is with you), my son? What (is with you), son of my womb? What (is with you), son of my vows?" (31:2). In terms of rank and courage, only a queen mother could administer such a rebuke to her powerful son without fear. Yoder (2009:263) notes that 'Lemuel's mother sternly cautions him about handing over his strength, (31:4-5).'

15.The poem's acrostic structure may account for the apparent mental jumps the poet makes (Whybray 1972:184). 
acrostic poems are easier to memorise. Secondly, it is a chiastic poem: Parallel verses cross over and pair up. ${ }^{16}$ For example, $\mathrm{A}$ and $\mathrm{A}^{\prime}$ are verse 10 and verse 30 to verse $31, \mathrm{~B}$ and $\mathrm{B}^{\prime}$ are verse 11 to 12 and verse 28 to $29 .{ }^{17}$ The verses correspond in this manner up to $G$ and $G^{\prime}$, verse 22 and verse 24 . Only verse $23, \mathrm{H}$ in this model, the verse dealing with the public respect the husband receives, stands alone, unpaired. ${ }^{18}$ This signifies its pre-eminence in the poem's structure and, arguably, the husband's importance in the life of the woman portrayed. Although the majority of the verses deal with the wife, the husband's significance and his role in society and in the marriage receive equal weight because of verse 23's key singleness and placement. ${ }^{19}$ Verse 23 both pivots the poem and is targeted towards its intended audience of young men looking for wives. ${ }^{20}$

The acrostic poem with its chiastic structure draws a strong picture of the kind of young woman a young man should look for and hope to find and the kind of marriage with her that is attainable. ${ }^{21}$ The woman of Proverbs 31 displays the characteristics that fulfil an earlier couplet in the book: 'He who finds a wife finds what is good and receives favour from the Lord' (18:22) [NIV]).22 Choosing an exemplary wife and making wise sexual choices like avoiding adultery (6:32) are two themes throughout Proverbs that form the foundation for a successful life. Significantly, the text introduces the wife as 'eset hayil', a woman of valour, wealth, strength and power (v. 10). When used for men, the word hayil denotes power in battle, and when used for women, it denotes exceptional and virtuous character. ${ }^{23}$ Because of her lifelong conduct and activities, the woman in the poem also can be described as a wealthy sage. ${ }^{24}$

The poem portrays this recurring theme in Proverbs: wise living (wisdom) is lived out in the world, and its cornerstone is the fear of the Lord (Walton \& Hill 2004:289-290). Using hyperbole as a teaching tool, Proverbs talks about alternatives:

16.The integration of the chiastic structure with the acrostic is outstanding, a feat clearly showing the poet's skill (Garrett 1993:248).

17.For an excellent explanation of the poem's structure and the importance of the husband, see Garrett (1993:248). Horne (2003:361) also draws on Garrett's work but does not emphasise the insights the poem gives on a successful marriage as does this article.

18.Murphy (1998:247), however, sees the poem as full of sly subversion and irony because the husband's role is 'so inconsequential' and the wife holds the power in the household. Farmer (1991:125) counters that the husband may be freed from duties on their large estate because of his wife's acknowledged competence as a manager.

19. Because the text mentions the city gates, perhaps the husband is a judge, one who administers justice in the city's most public arena (Smith 2002:339).

20.Garrett (2008:575) and Apple (2011:178), on the other hand, sees the husband a bit differently as one 'who, thanks to her backing, has the leisure to sit at the city gate and discuss civic affairs.

21.Ives and Ives (2001:47-50), noting that most of life takes place after the wedding provide a framework for ongoing work on the new marriage, including developing and sustaining a faith-based lifestyle and managing finances.

22.Murphy (1990:137) draws a parallel with finding a good wife and finding Lady Wisdom ( $\operatorname{Pr} 18: 22 ; 31: 10 ; 8: 35 ; 3: 13 ; 8: 17)$. The issue of finding wisdom is one of life and death, and arguably, so is the issue of finding a good wife. This article asserts that the woman in the marriage described in Proverbs 31:10-31 exemplifies wisdom in practice for many reasons including her conscious choice to use words wisely (v. 26).

23.Likewise, Ruth and Boaz are described by the term hayil (Rt 2:1; 3:11).

24.A sage in Ancient Israel served as a member of the royal cabinet, as a counselor, scribe, specialist in rhetoric, judge, lawyer, accountant (see Perdue 2008:103). a life that brings benefit to the community and honour to the individual versus a life that drains community resources and yields a verdict of shame on a person. This article asserts that Proverbs' concluding poem illustrates these and other wholesome principles.

\section{Time frame}

Significantly, the poem indicates that, as far as time is concerned, the overall scope is long term, presenting a picture covering many years, presenting a picture covering many years; however, the poem's details combine past, present and future. It presents accomplishments in a woman's life that happen in various seasons. ${ }^{25}$ This article not only sees the poem as giving glimpses into a working marriage, but also stresses that the poem shows the couple's married life over many years. ${ }^{26}$

The poem introduces a young woman of noble character who seeks to bring her young husband 'good, not harm, all the days of her life' (31:10b, 12b [NIV]). The poem provides numerous examples of how she accomplishes doing him 'good and not harm' (vv. 13-27). It ends with the children from the marriage being old enough to rise up in respect (possibly at some public function) and pronounce their mother happy or blessed (v. 28). The poem's narrator states the reward her life has earned, and the praise her works deserve at the city gate (v. 31). I think a major misconception of the poem is that this amazing woman does all these things aonce and all the time. Instead, the poem lists various accomplishments that happen over time but are a pattern in her life.

\section{A comparison between Lady Wisdom (Proverbs 8-9) and the Proverbs 31:10-31 woman}

Although Lady Wisdom ${ }^{27}$ and the Proverbs 31:10-31 woman share similarities, they differ strongly in four major respects. ${ }^{28}$ Consequently, any assertion that the Proverbs 31 woman is Lady Wisdom in human form goes too far.

Firstly, the Proverbs 31 woman creates in her home and landholdings (31:13-27) whilst Lady Wisdom's playground is creation and the entire world (8:22-31). Secondly, Lady Wisdom talks - and talks a lot. Verbose, she carries on the tradition in Wisdom Literature of long, uninterrupted speeches. On the other hand, the Proverbs 31 woman seems to consider her words beforehand. When she speaks, it is with wisdom; her speech contains faithful instruction (31:26).

25.The woman of Proverbs 31 arguably had seasons or times in her life to make clothes, spin wool and flax, go shopping, take trips and find exotic foods, engage in business practices, conceive and bear children, decorate her home, acquire fine furnishings, instruct servants, accumulate wealth, buy a field, et cetera.

26.I believe I am unique or at least somewhat exclusive in stressing that this poem encompasses years of married life and advocates the long-term benefits of good habits and wise choices.

27. Murphy (1990:133) considers Lady Wisdom 'the most striking personification in the Bible.'

28. Habel (1972:157) sees Lady Wisdom as a symbol who moves throughout Proverbs. 
TABLE 1: A comparison or contrast of Lady Wisdom and the Proverbs 31 woman.

\section{Lady Wisdom (Pr 8, 9)}

Is comfortable with men (8:4)

Explains the fear of the Lord $(8: 13)$

Her instruction is above silver; her wisdom more precious than rubies (8:10-11) Possesses sound judgement (8:14)

Says the man who listens to her is blessed (8:34)

Says those who find her find life and receive favour from the Lord (8:35)

Builds a house (9:1)

Offers hospitality to the simple and strangers (9:2-5)

Directs servants and treats them well (9:2)

Says her ways lead to longevity (9:11)

She plays (8:30-31)

Seems eternally young and playful $(8: 25,30-31)$

God enjoys her presence (8:30-31)

Holds riches and honour (8:18)

Speaks loudly in the marketplace (8:1)

Has no mentioned offspring

Is the Lord's darling and delight (8:30-31)

Shows wisdom via words $(8,9)$

Boldly teaches in the marketplace (8:1-21)

Provides a banquet with meat and wine (9:1-5)

Hates evil, pride, arrogance, perverse speech (8:13)
Is the opposite of Lady Folly (9:13-18)

Seeks to do good to others via instruction (8:1-11)

Exhibits analytical thinking skills

The Proverbs 31:10-31 woman

Avoids deceptive charm (31:30)

Is recognised by men at the city gate (31:31)

Others see she fears the Lord (31:30)

Her worth is above rubies (31:10)

Speaks wisely (31:26)

The poem says her husband is blessed and listens to her faithful instruction $(31: 11,26)$

Does good to her husband every day (31:12)

Her husband finds this noble woman (31:10)

Builds a wonderful home over many years

Opens her hands to the needy (31:20)

Arises early and treats servants well (31:15)

Has a long and productive life $(31: 29,31)$

She enjoys work (31:17)

Seems middle-aged because of the age and observations of her children (31:28)

Her husband enjoys her and praises her (31:28-29)

Laughs at future worries about want (31:25)

Is invited to participate at the city gate (31:31)

Has children (31:28)

Fears the Lord (31:30)

Shows wisdom via practical skills (31:13-25)

Instructs servants $(31: 15,27)$

Seeks and finds food from afar (31:14-15)

Hates sloth and is a model of productivity and industry (31:13-19)

Exhibits critical thinking skills by planning for the future $(31: 16,21)$

Thirdly, the Proverbs 31 woman is mortal. Lady Wisdom, however, seems to possess divine attributes. She sees God, even playing alongside him as he creates (8:30). She may be a kind of supernatural being like the Behemoth (Job 40:15-24) and the Leviathan (Job 41) that possess fearsome qualities. Fourth, the two women portray the two broad avenues of wisdom: wise verbosity and wise skills. ${ }^{29}$

It is interesting to note that, if the poem concluding Proverbs reflects women in the Persian time or if the book was compiled well after Hezekiah's time (715-686 BCE), some insights from Amos might apply. Amos 4:1 offers a sarcastic commentary on some rich, fat women in an earlier time ${ }^{30}$ who oppress the poor, crush the needy and arrogantly command their husbands to bring drinks. The woman of Proverbs 31 exhibits the opposite of this biblical portrait. She is courteous to all, even to the poor, and is known for her energy, restraint, faithfulness to her husband and graciousness.

\section{Voice}

The poem's 'voice' could be that of a mother admonishing her son about a wife (vv. 1-2) (Smith 2002:336). It could be a happy husband ${ }^{31}$ or the parents mentioned in Proverbs 1:8 or a long-time observer of a good marriage. However, it is clear that the woman described in Proverbs 31:10-31 is not the voice (Branch 2008b:921). I believe the voice is that of a friend of the family, a keen but kind observer, one who has known

29 .Walton and Hill (2004:289) point out that the Hebrew concept of wisdom covers artisan skills, scientific knowledge, etiquette, philosophy, psychology, politics, sociology, scientific knowledge, and jurisprudence, to name some.

30.Perhaps during the reign of Uzziah (792-740 BCE; Am 1:1)

31. Horne (2003:360) believes that the voice in verses 11 to verses 12 comes from the husband and provides a view of the pragmatic aspects of Lady Wisdom's character. the man and the woman for decades, visited their hospitable home frequently and was at ease with them. ${ }^{32}$

\section{Basic ideas in the acrostic poem}

The poem's tone contains admiration. ${ }^{33}$ In addition, the text presents the view that this is a marriage of equals (see Tichenor 2005:17). Some point out that this equality is surprising because the poem's setting is a patriarchal society. However, other scholars observe equality in love is neither surprising nor unusual in Hebrew poetry, for the Song of Songs presents equality in love between the young man and young woman. ${ }^{34}$ Furthermore, Proverbs indicates home instruction and responsibility as equally shared by the father and mother $(1: 8 ; 10: 1 ; 23: 22,25)$.

Both the husband and wife in the poem act deliberately, wisely and wholeheartedly in giving to their marriage..$^{35}$ The man and woman bring to their marriage different temperaments, gifts and interests, but they approach the marriage and interact within it as equal partners. They listen to each other, trust each other and function as a team. ${ }^{36}$

32. However, I also acknowledge the possibility of a different view on voice based on a different interpretation of the acrostic poem: The poem could be a literary

33.Davis (2009:276) notes that the poem is 'the longest admiring description of any ordinary person - that is, not Moses or Jesus or Paul - in the entire Bible.

34.Citing Trible and Brenner, Sparks (2008:299) observes that the male and female in the Song of Songs are naked and without shame and display a personal equality in sexual matters throughout the poem.

35.Writing on Proverbs 8:22-31, the earliest biblical example which presents Wisdom as a person, Pentiuc (2001:262 \& 261) says that 'the birth of Wisdom is an act of self-offering, an offering of love, an act of deliberation on God's part.'

36.Augsburger (1973:37) points out that some men consider a woman an inferior being, one who must be set in a subordinate, obedient position and accept her role humbly in sweet submission. 'That verdict,' he (1973:37) continues, 'denigrates both male and female.' The egalitarian marriage relationship portrayed in the both male and female.' The egalitarian marriage relationship portrayed in the
closing poem of Proverbs gives insights into an ongoing, lifelong commitment between two people that is open for the world to see. pn a different interpretation of an ideal type.
projection 
They, by their wise choices, pursue wisdom throughout their lives. ${ }^{37}$ They show, by their wise actions, that wisdom principles work in a marriage.

The text presents the idea that the young husband began his marriage with starry-eyed wonder: He is amazed that he has found a young woman of such character and worth (v. 11). For her part, the young wife began her marriage by deciding to bless her husband - in other words, to do him good - all the days of their life together (v. 12). ${ }^{38}$ They have spent their married years developing these traits.

In this marriage, there seems to be no competition, no open conflict and no effort to control or to manipulate the other person. Significantly, neither party seeks to overhaul the other. ${ }^{39}$ These marriage partners complement and complete each other. They complement - truthfully speak well of each other, too. They build on their strengths, letting their different personalities and interests bring their union vigour, variety and energy..$^{40}$ The marriage portrayed in this passage shows a successful (and arguably adjustable and flexible) combination of intimacy, coactivity, individual activities and activities performed from a distance (see Worthington (1989:69). Together they work for the betterment, the wellbeing, of their family, their community and each other. Others recognise that the fear of the Lord (v. 30), a principle in Proverbs, influences their choices.

\section{What the passage says about the husband}

Let's consider this insight firstly: Proverbs 1:8 states the desire of the father and the mother to instruct their son; and Proverbs 31:23 states that the husband is respected and is a leader in the land..$^{41}$ Could it be that the teaching contained between these verses, if followed, seems to assure the young son of the strong probability that he will achieve a high level of leadership and respect as an older adult? The text does not say, but it seems to present this possibility. Traditional Jewish scholarship acknowledges the importance of verse 23 by saying the husband is a Torah scholar certain to be greeted in the next world by the sages (see Apple 2011:179-180).

Arguably, Proverbs 31:10-12 shows the husband's character as a young man. For example, verse 10 presents the idea of a

$37 . Y$ oder $(2009: 263)$ argues this way: "The pursuit of wisdom, though wearying, is urgent and lifelong.

38. Actually, the poem gives evidence that both partners have a genuine commitment to the other because each places the interests of the other before his or her own (Tichenor 2005:23). The prime example, however, is the woman who purposefully does good to her husband (31:12). Achtemeier (1976:92-93) writes that a Christian woman in a Christian marriage 'desires first of all that her husband be fully human,' and defines fully human within the context of the Christian faith as being 'a and defines fully human within the context of the Christian faith as being 'a
loving, trusting, caring, faithful, whole person in relation to God and his family and neighbors.' Achtemeier's statements provide a foundation for this article.

39.Each marriage involves the union of two completely different people. Tournier (1969:37) writes that two 'people so very different by nature are nevertheless made to complement each other, that through each other they may discover so much of what they've not known or sensed before. This is one of the purposes of marriage.'

40.Curran (1983:71) notes that a healthy family's basic mood is positive; hope prevails. Granted, stresses may come and may even last for years, but not only are they considered temporary but also a family with this kind of vigor 'seems to dredge up resources to deal with them!

41.It is interesting that the son and husband figure eight verses from the beginning and eight from the end in Proverbs. search because a wife of noble character is sought and found..$^{42}$ An earlier idea in Proverbs is that a commendable young man seeks a good wife as he would any gift from the Lord. The New International Version renders Proverbs 18:22 this way: 'He who finds a wife finds what is good and receives favour from the Lord.'

Proverbs 31:10a builds on this theme by asking, 'A wife of noble character, who can find?' (italics added). Quite possibly, the husband in the poem, as a young man, looks for a wife. Arguably, he makes a list. Topping it is nobility of character (valour, courage, strength and the ability to overcome - all aspects of the word hayil) (Strong 2007:1481). This list includes a personal preference: confidence. The young man wants to be able to put his confidence in a young woman. ${ }^{43}$ He seeks a young woman who already carries her own weight, so to speak. She does not burden her parents and likewise will not burden him. Her life patterns or habits, established already as a young woman, indicate that he can confidently expect good from her all the days of his life. Arguably, the husband in the poem has been trained by his parents as a young man to have broad, long-term goals. Essential to meeting them is the foundational choice: the right wife, the right lifetime partner.

Arguably as a young man, this husband listened to the teachings of his father and mother $(1: 8 ; 2: 1 ; 3: 1 ; 4: 1 ; 5: 1 ; 6: 1$, $20 ; 7: 1$ ). These teachings broadly include the benefits of wisdom (chs. 2-3), the supremacy of wisdom (ch. 4), specific warnings against adultery (ch. 5), specific warnings against aspects of folly - a bad bargain, laziness, plotting evil and sleeping with a neighbour's wife (ch. 6) - and even more warnings against adultery (ch. 7).

Notice the significant silences in the poem's opening verses. Nothing is mentioned about love or falling in love, or about wealth, piety or beauty. As the poem progresses, change is acknowledged as happening over the years, but physical beauty is called fleeting (v. 30a) and the family's wealth, accumulated over years, is acknowledged (vv. 14, 22b; 24-26). The young man seems to have had longterm goals in mind as he came of age and looked for a wife. Character heads the list: it exceeds rubies. Arguably, the young man reasoned that, potentially, character outweighs any social status her parents possessed, or dowry they could give her, or her own beauty. A pretty face and outward charm remain initially unmentioned as requirements. Indeed, the poem ends with them being mentioned negatively as fleeting and deceptive (v. 30a) and even found lacking when contrasted to a woman who fears the Lord (v. 30b).

Arguably as a young man, the husband thought about the training of his parents, his own needs and his future. He 42. By his actions, the young man shows that he is a wise man who submits his life to
a righteous order. Wisdom is more than a practical application of knowledge. It
also denotes a fixed, righteous order under which a righteous person can live and
confidently submit his or her life (Waltke 1979:238).

43.Davis (2009:276) offers this observation that I find quite insightful: the noble woman in Proverbs represents a source of security for her husband as well as an image and source of strength for the wider community. 
sought to make a wise choice in life's most long-term and intimate relationship: marriage. The poem shows the wife plans for the future by buying a field. Probably, the husband likewise exhibited assessment skills by planning for his future by choosing a young woman of character. His direct quotation praising his wife (vv. 28-29) not only shows his appreciation of her but also attests to his delight in having successfully found, many years before, such a young woman.

The husband, now a recognised leader, has followed the teachings of Proverbs by shunning perverted speech and avoiding the way of evil men (Pr 2:12). His life, lifestyle and business manners favour harmony. ${ }^{44}$ Like Lady Wisdom, he seeks order and stability.

The body of the poem, verse $12 \mathrm{ff} .$, backs up how this young woman throughout her life brings this young man, now her husband, 'good and not harm' all the days of her life. Verse 12 is an editorial statement; it must be backed up by what follows. ${ }^{45}$ The poem delineates the good she does principally to her husband and tangentially to her children, her servants and her wider community.

\section{How they use words}

The passage emphasise the wise use of words by both the husband and wife. ${ }^{46}$ This is consistent with a theme throughout Wisdom Literature, namely that the tongue of the wise brings healing ( $\operatorname{Pr} 12: 18)$ and that he who guards his mouth and his tongue keeps himself from calamity (21:23). ${ }^{47}$ The husband constantly praises his wife, enumerating her accomplishments (see Smith 2002:319). The wife, seemingly less prone to speech, thinks before she speaks and thus, arguably, avoids conflict. When she gives her opinion, she clothes her truthful words in kindness (v. 26). The husband heeds her voice, for he has observed throughout their life together that, when she speaks, she speaks wisely (see Bakon 2008:223-224). She appears to practice what modern counsellors call holy listening, that is, listening as an act of prayer (Kornfeld 2005:61). An alternative way of using words that amounts to cruelty is honesty without compassion (Karasu 2006:141).

\section{Each allows the other to express love differently}

The husband of Proverbs 31 tells his wife by his words and deeds that he loves her. As a man of standing in the community, he demonstrates his love by providing well for his family. The wife tells her husband by her actions that she loves him: she makes him look good amongst the

44.1 am grateful for these insights on harmony by Kenik (1976:400), who sees similarities between Psalm 101 and Proverbs.

45.I have written extensively on this literary trait; see Branch (2009:9-17), especially pages 12-14.

46.Bender (1997:111) believes that positive messages - defined as appreciation affirmation and praise - 'are the soul food that nourishes a marriage.'

47.Communication, whether good or bad, contributes to all relationships. Curran (1983:55) lists several positive characteristics that mark a family whose members communicate well. towns people; she is faithful to him; she seeks to do him good and not harm (31:12). Arguably, a man's primary psychological need is respect (see Eph 5:33). The woman of Proverbs 31 respects her husband. Indeed, the whole land respects him (v. 23).

This husband trusts his wife (v. 11). His honour as a man rests securely with her. ${ }^{48}$ Her life and her activities enhance his standing in the community. His enjoyment of her phenomenal energy encourages her to do what she loves best: to work even harder and to produce even more (v. 17). ${ }^{49}$

The woman has found that hard work (vv. 13-19), kind words (v. 26), a generous spirit (v. 20), good grooming (vv. 24-25), raising obedient children (v. 28), an ability to contribute to the family's income (v. 24) and a warm bed (v. 22) have kept the interest and love of the man she married in her youth. The text hints at the richness of their sexual union because it notes the multiple coverings (which the woman has woven) on her bed (v. 22) (italics added). She has made her bedroom a place of beauty and refuge. ${ }^{50}$

\section{Each works in different ways for the betterment of the family}

The husband enjoys a key position in the city. Over the years, his prominence in the community has risen. As a man whom the text observes is respected, the husband avoids actions and speech that 'sow discord amongst brothers' (Pr 6:19). That kind of behaviour 'contributes to the ruin of society' (Kenik 1976:401). In this and other ways, he follows principles of Wisdom Literature. Because his wife manages their household so well, he has the time and freedom to devote his energies to his business. The text does not describe his business but instead concentrates on his prominence and standing.

Like her husband, the wife functions well in administration. She works harder than all her servants, even labouring beside them. ${ }^{51}$ She gets up before dawn and sees that they eat well (v. 18). She makes her own clothes (v. 24). ${ }^{52}$ Significantly, she works with her hands and is actively involved in wool and flax and in weaving (vv. 13,19). Throughout the poem, she bears a flesh-and-blood resemblance to Lady Wisdom in Proverbs 8 and 9 . Her practical qualities, which are emphasise more than is her piety, make her an ideal companion and complement to her husband (Whybray 1990:111). She shuns ill-gotten gain, clearly a teaching in Proverbs (1:19; 10:2). In a

48.The woman is what Cloud and Townsend (1995:144) call a 'safe person'. The characteristics of such a person include acceptance of another and giving another an opportunity to grow.

49.Farmer (1991:124-125) writes that this woman's reservoirs of energy and endurance are truly formidable.

50.An enjoyable sexual relationship between a husband and wife is encouraged and praised in Proverbs 5:15-19.

51.Augustine commends the woman for 'valiantly girding her loins' and serving with chastity and ready devotion (Wright 2005:187).

52.Ambrose sees the woman's skill with the needle on an allegorical level. Her garments are pleasing things of beauty and represent an interaction of faith and works (Wright 2005:188). 
limited but practical portrait of Lady Wisdom, the woman of Proverbs 31 is both creator and creative (see Horne 2003:362). Significantly, she is a fine businesswoman. ${ }^{53}$

\section{This couple appreciates the gifts of the other}

There is no hint in the poem of the control or superiority of one partner over the other. There is no indication of trying to make over the other into a pre-determined image or into a clone of the other partner. Instead, the marriage gives each partner the freedom to grow. The woman - with no textual reference that she consults her husband beforehand - engages in real estate. Specifically, she considers a field and buys it, and from these earnings she plants a vineyard (v. 16). Decision-making abilities are part of her nature; she leads by example. Her husband enjoys her energy, the significant profit she brings to the family, the status her good name brings him, her many enterprises and her flair at running their household smoothly.

In turn, the woman enjoys the respect her husband commands as a city leader and power figure in the land (v. 23). His status gives her the public backing for her many enterprises. Significantly, the text raises the possibility that the husband and wife are financially independent of each other. Furthermore, the Proverbs 31 woman is neither housebound nor submissive in a grovelling way (see Davis 2009:276).

\section{Trust and honour}

Each trusts the other's judgement (v. 11). The husband appreciates his wife's sound business sense. Like him, she has the ability to make money. ${ }^{54}$ The poem ends with what seems to be an unexpected public honour that comes to the wife. The city leaders, her husband's associates, recognise her abilities and possibly ask her to take part in deliberations that affect the city (v. 31). She knows how to make an honest profit through bargaining, investment, long-term planning for the future and her own industry. City leaders trust her because she is known to seek the good of others. The excellent way she manages her home serves as a springboard for her wider influence for good in the community; she seeks the welfare and happiness of the whole society (see Miller 2004:299). Because she listens, others listen to her. Significantly, this husband and wife seem to know that, when one of them is honoured, the whole family receives honour. In this, they exemplify this teaching in Proverbs: the wise inherit honour (3:35 [NIV]). The couple in Proverbs 31:10-31 and the townsfolk, their neighbours, follow the principle of Wisdom Literature of directing credit for this family's blessings toward the Lord (v. 30b). ${ }^{55}$

53.Whilst she certainly is a woman of worth, "her worthiness is business-like, pragmatic and thrifty,' writes Apple (2011:178).

54.Deuteronomy 8:18 says this: 'But remember the Lord your God, for it is he who gives you the ability to produce wealth, and so confirms his covenant, which he swore to your forefathers, as it is today.'

55.The concluding poem shows that 'our relationship with God is at every moment inseparable from our relation to the material world,' as Davis (2009:276-277) observes.

\section{Prosperity}

This marriage enjoys financial prosperity. ${ }^{56}$ The many financial aspects contained in this acrostic poem may provide a clue to its dating. The Proverbs 31 woman, as she is known, could well reflect a composite portrait of the industry and character of many 'ideal wives' in the Persian period (see Yoder 2003:428, 446-447). ${ }^{57}$ The Proverbs woman dresses elegantly in linen, an expensive fabric, and prefers the royal colour, purple (v. 22); quite likely she is a skilled tailor (v. 19) ${ }^{58}$ Her home displays their wealth in tasteful ways that may well include foreign furnishings (v. 14). ${ }^{59}$ The domicile portrayed is not a royal palace but a home of prosperity and elegance, one with servants and one which the wife ably manages (see Apple 2011:178). The idea that her lamp does not go out at night (v. 18) also indicates prosperity because oil was expensive (Whybray 1994:428). The woman develops her skills and interests (v. 13), specifically in weaving wool and flax. The husband also seems fulfilled in his work amongst the elders at the city gate; his is a prominent position (v. 23). In contrast to other parts of Proverbs that condemn pride and greed $(11: 2 ; 15: 27)$, this section commends the enjoyment of wealth justly earned over a long period, the accumulation of meaningful treasures and the beautification of the home. Similarly, this poem portrays ambition positively (see Horne 2003:363). This biblical text shows that many marital benefits occur when both parties work. ${ }^{60}$

\section{Planning for the future}

This family plans for the future by investing in the ancient equivalent of insurance policies and long-term financial investments. For example, the wife considers a field ${ }^{61}$ buys it and from its earnings plants a vineyard, something that takes years of care before producing a crop (v. 16).

These investments bring the family a sense of accomplishment and joy. Knowing they are secure financially gives this couple an exuberance, confidence and generous spirit (v. 20). This family's wealth comes from honest labour and diligence, and probably because its members fear the Lord. ${ }^{62}$

56.The theme of honourable and achievable prosperity occurs throughout Proverbs Prosperity comes via wise choices made consistently over a period of time (see Branch 2006). Poverty results from foolish choices and habits. Whilst the woman's lifestyle acknowledges the poor and willingly helps them ( $\operatorname{Pr} 31: 20)$, it also provides an example of an alternative to poverty. Wisdom literature seeks order, provides an example of an alternative to poverty. Wisdom literature seeks order, contains broad principles and offers an explanation that both prosperity and adversity come from the hand of the Lord (see Walton \& Hill 2004:287, 289, 290). Proverbs offers
generalisations, not promises (Walton \& Hill 2004:301).

57.'In short,' Yoder (2003:446) writes, 'her socio-economic activities mirror those of Persian-period women, particularly those of affluence or position.'

58.Van Leeuwen (2007:85) sees a link between the valiant woman of Proverbs 31 with her ability to weave for her home and for market and 'all the wise hearted women' of Exodus 35:25-26 who weave cloth for the Tabernacle.

59.'Linen' implies Egypt and 'purple' may describe furnishings from Phoenicia (v. 23; Garrett 1993:251).

60. Rowatt and Rowatt (1980:36-40) list several possible categories of growth that working spouses may experience, including that each partner is free to grow and to seek personal satisfaction in work.

61.Horne (2003:363) notes that the woman's diligence and hard work denote cleverness; furthermore, her actions regarding the field are 'wisdom in action.'

62.Whybray (1990:117) adds that this family's steady increase of wealth appears to come without a consuming ambition for wealth. 
The woman provides ample clothes (even double layers) for her household and servants for the winter (v. 21). ${ }^{63}$ Arguably, a woman's primary psychological needs are love and security (see Eph 5:33). This Proverbs 31 woman feels so secure in her marriage and in her family's financial standing that she faces the future with laughter (v. 25). ${ }^{64}$

\section{Silences in the passage}

Proverbs 31:10-31 unquestionably presents a happy, healthy marriage and family. A silence in the text is the absence of the word love. However, there is much textual evidence in verse 10 to verse 31 that the two love each other. ${ }^{65}$ Another significant silence is the depth of the spirituality of both the husband and wife. Nonetheless, the woman seems to combine the tradition in Wisdom Literature of the fear of the Lord and acting wisely without orally preaching about a life of piety and prayer. ${ }^{66}$

The marriage picture presented in Proverbs 31:10-31 shows no sign of physical or emotional abuse. Modern research sheds light on the partners in an abusive marriage (see McCue 1995:108-109). The traits of an abuser include low self-esteem, a belief in male superiority, the tendency to blame others for his actions, a pathological jealousy and a refusal to believe that his actions may have negative consequences. An abusive man is possessive of his wife's time; he tends to be jealous. Significantly, the husband of the Proverbs 31 woman shows none of these traits.

Likewise, modern research shows that an abused woman also may have some distinctive traits. For example, an abused woman may adopt a strategy for coping with abnormal and unusually frightening experiences (Wexler 2003:46). Her strategy likely involves silence, denial, passivity, instant obedience, no dialogue, isolation and minimalising herself. $^{67}$ She adopts an attitude of learned helplessness (see Clarke 1986:46). Significantly, the woman of Proverbs 31 shows none of these traits.

The Proverbs text instead presents a marriage that the neighbours probably envy. The poem, which ends the book of Proverbs, shows such a high level of integrity for both the man and the woman that their excellence of character can only come from a firm religious faith. ${ }^{68}$ Note as well that the inclusion, the fear of the Lord, brackets the book $(1: 7 ; 31: 30)$. An inclusion points inward, indicating that everything in between should be read in light of this repeated statement. Proverbs 31:10-31 displays characteristics of two people,

63.Clothing is important in this poem. Making things like sashes and tapestries from her weaving endeavors and making clothing for her household are practical aspects of her industry and skill (vv. 21b, 22, 24). Horne (2003:364-365) notes that verse 23 the verse about her husband, is in the middle of this section on clothing (vv. 21-25).

64.Lady Wisdom also laughs. Lady Wisdom's laughter (1:26) reflects the judgement she knows is coming upon the wicked (Waltke 1988:14).

65.Knieps-Port le Roi (2001:111) puts it this way: 'A love between two persons which commits itself absolutely to the other has its ultimate basis in the experience of God.' Maybe that is why the poem talks about the fear of the Lord (v. 30).

66.Apple (2011:179); see Proverbs 1:7, 9:10; cf. Psalm 111:10; Job 28:28; Ecclesiastes $1: 14$

67.Coping skills include anger, shock, nightmares, dissociation (see McCue 1995:100).

68.Whybray (1972:187) and Curran (1983:22) cites sharing religion as a trait of a healthy family. a husband and wife, who are open, vibrant, happy, busy, fruitful, prosperous, prone to laughter and respected. These characteristics spill over to diligent servants and appreciative children ${ }^{69}$ and multiple business associates.

\section{Results}

The acrostic poem contained in Proverbs 31:10-31 favourably presents the woman, the husband, their children, their servants and their life; indeed, its tone is triumphant. As is consistent in other places in the biblical text, the narrator, or in this case the poet, approves of the energetic activities mentioned, for they certainly produce an exemplary family. The husband and wife in Proverbs 31:10-31 have created a home in the finest sense of the word. The text shows that this man and this woman are so happy, content, satisfied and fulfilled in their marriage that the other choices presented in Proverbs - that of seeking sexual fulfilment outside the marriage for the man and that of becoming an adulteress for the woman (Pr 5) - are not even considered! The man and woman depicted in this poem are middle aged. The marriage portrayed in the poem, however, shows a unity that is often absent in modern marriages in midlife, for the poem's husband and wife do not 'move past each other in different directions and at different paces' but instead seem to share an agreed upon balance of power (see Blacker 1999:291). Seeking order, they avoid chaos - both principles in Wisdom Literature.

The couple has achieved what seems so commonplace but is so rare: an understanding of each other. This husband and wife are so busy enjoying their fulfilling, productive lives $^{70}$ that they do not have the time to engage in adultery, laziness, drunkenness, nagging or gossiping, other lifestyles presented in Proverbs.

In a manner more akin to a water-colour painting than to a photograph, the poem presents a practical picture of Lady Wisdom of Proverbs 8 and 9 in action. The woman in the concluding poem of Proverbs is broadly drawn as downto-earth, skilful, prudent, wise and industrious. ${ }^{71}$ She runs an extended household and complicated estate excellently - and she enjoys her labours (see Farmer 1991:126). This man in the concluding poem in Proverbs, who has risen to become a leader in the land, has found that encouraging his wife with constant praise, providing a setting in which she develops her gifts ${ }^{72}$ and expressing his confidence

69.The biblical passage also hints at the long-term attitude in the home toward parenting and children: 'Her children arise and call her blessed' (31:28a). Worthington (1989:67) notes that unhappy and happy couples exhibit different patterns of marital satisfaction at all points in a family life cycle. It would seem that the couple in Proverbs 31:10-31 has a happy marriage throughout its many stages in the childrearing process.

70.The poem gives every indication that the habits of productivity, energy, doing good, and being part of the covenant community will continue unabated when the children grow up and have homes of their own (see Blacker 1999:295).

71. Horne (2003:365) sees Proverbs' closing poem as 'leaving no doubt in readers' minds' about why ancient sages believed a society succeeds: the poem shows that the woman's 'strength, determination, skill, diligence, devotion, and cleverness provide the foundation for the success of her family and the success of her community.'

72.Achtemeier (1976:93) notes that 'husbands foster Christian liberty when they allow their wives to exercise their full personhood, including their minds and strengths.' 
in her abilities to bless the family have brought him an amazingly happy, satisfying and successful life. Together, this remarkable couple graciously provide a glimpse into a happy marriage founded on principles prolific throughout Wisdom Literature. Together they model - even incarnate a lifetime of finding and making wise choices.

\section{Acknowledgements Competing interests}

The author declares that she has no financial or personal relationship(s) which may have inappropriately influenced her in writing this article.

\section{References}

Achtemeier, E., 1976, The Committed Marriage, The Westminster Press, Philadelphia. Apple, R., 2011, 'The Two Wise Women of Proverbs Chapter 31', Jewish Bible Quarterly 39(3), 175-180.

Augsburger, D.W., 1973, Cherishable: Love and marriage, Herald Press, Scottdale.

Bakon, S., 2008, 'Two Hymns to Wisdom: Proverbs 8 and Job 28', Jewish Bible Quarterly 36(4), 222-230.

Bender, S.G., 1997, Recreating marriage with the same old spouse: A guide for couples, Westminster John Knox Press, Louisville.

Blacker, L., 1999, 'The launching phase of the life cycle', in B. Carter. \& M. McGoldrick (eds.), The expanded family life circle: Individual, family, and social perspectives, pp. 287-306, Allyn and Bacon, Boston.

Branch, R.G., 2006, 'Life's choices: A play based on eight characters in Proverbs', Society of Biblical Literature Forum, viewed 06 June 2011, from http://www.sblsite.org/publications/article. aspx?articleld $=488$.

Branch, R.G., 2008b, 'Women', in T. Longman III \& P. Enns (eds.), Dictionary of the Old Testament: Wisdom, Poetry \& Writings, pp. 916-925, InterVarsity Press, Downers Grove.

Branch, R.G., 2009, Jeroboam's wife: The enduring contributions of the Old Testament's least-known women, Hendrickson Publishers, Peabody.

Brown, W.P., 2011, 'The Wonder of It All: Faith, Creation, and Wisdom', Journal for Preachers 34(4), 33-38.

Camp, C., 1985, Wisdom and the feminine, Almond Press, Sheffield.

Clarke, R.-L., 1986, Pastoral care of battered women, The Westminster Press, Philadelphia.

Cloud, H. \& Townsend, J., 1995, Safe people: How to find relationships that are good for you and avoid those that aren't, Zondervan, Grand Rapids.

Crook, M.B., 1954, 'The Marriageable Maiden of Prov. 31:10-31', Journal of Near Eastern Studies 13, 137-140. http://dx.doi.org/10.1086/371204

Curran, D., 1983, Traits of a healthy family: Fifteen traits commonly found in healthy families by those who work with them, Winston Press, Minneapolis.

Davis, E.F., 2009, 'Surprised by Wisdom: Preaching Proverbs', Interpretation 63(3) 264-272. http://dx.doi.org/10.1177/002096430906300305

Duvall, J.S. \& Hays, J.D., 2012, Grasping God's Word: A hands-on approach to reading, interpreting, and applying the Bible, 3rd edn., Zondervan, Grand Rapids.

Farmer, K.A., 1991, Who knows what is good? A commentary on the books of Proverbs and Ecclesiastes, William B. Eerdmans Publishing Co., Grand Rapids.

Fox, M.V., 2009, Proverbs 10-31: A new translation with introduction and commentary, Yale University Press, New Haven.

Garrett, D.A., 1993, Proverbs, Ecclesiastes, Song of Songs, Broadman Press, Nashville.

Garrett, D.A., 2008, 'Proverbs 3: History of interpretation', in T. Longman III \& P. Enns, (eds.), Dictionary of the Old Testament: Wisdom, poetry \& writings, pp. 566-576, InterVarsity Press, Downers Grove.

Goettler, W., 2009, 'Proverbs 9:1-6', Interpretation 63(3), 290-292. http://dx.doi.org/ $10.1177 / 002096430906300309$
Habel, N., 1972, 'The Symbolism of Wisdom in Proverbs 1-9', Interpretation 26(2), 131-157. http://dx.doi.org/10.1177/002096437202600201

Horne, M.P., 2003, Smyth \& Helwys Bible commentary: Proverbs-Ecclesiastes, Smyth \& Helwys Publishing Inc., Macon.

Ives, J.P. \& Ives, S.C., 2001, Growing love in Christian marriage: Official United Methodist Resource, rev. edn., pastor's manual, Abingdon Press, Nashville.

Karasu, T.B., 2006, The spirit of happiness: Discovering God's purpose for your life, Simon \& Schuster, New York.

Kenik, H.A., 1976, 'Code of Conduct for a King: Psalm 101', Journal of Biblical Literature 95(3), 291-403. http://dx.doi.org/10.2307/3265272

Knieps-Port le Roi, T., 2001, 'Marriage and the church: Theological reflections on an underrated relationship', in A. Thatcher (ed.), Celebrating Christian marriage, pp. 105-118, T\&T Clark, Edinburgh.

Kornfeld, M., 2005, Cultivating wholeness: A guide to care and counselling in faith communities, Continuum, New York.

Lostracco, J. \& Wilderson, G., 2008, Analyzing short stories, Kendall/Hunt Publishing Company, Dubuque.

McCreesh, T., 1985, 'Wisdom as Wife: Proverbs 31:10-31', Revue Biblique 92, 25-46.

McCue, M.L., 1995, Domestic violence: A reference book, ABC-CLIO, Inc., Santa Barbara. Miller, J.W., 2004, Believers church Bible commentary: Proverbs, Herald Press, Scottdale.

Murphy, R.E., 1990, The tree of life: An exploration of Biblical wisdom literature, William B. Eerdmans Publishing Co., Grand Rapids.

Murphy, R.E., 1998, Proverbs, Thomas Nelson Publishers, Nashville.

Pentiuc, E.J., 2001, 'A Self-Offering God and His Begotten Wisdom (Proverbs 8:22-24)', Greek Orthodox Theological Review 46(3-4), 255-265.

Perdue, L.G., 2008, The sword and the stylus: An introduction to wisdom in the age of empires, William B. Eerdmans Publishing Company, Grand Rapids.

Roberts, C., 2004, Founding mothers: The women who raised our nation, Harper Collins, New York.

Rowatt, G.W. \& Rowatt, M.J., 1980, The two-career marriage, The Westminster Press, Philadelphia.

Smith, M.E., 2002, 'Proverbs', in C.C. Kroegter \& M.J. Evans (eds.), The IVP Women's Bible Commentary, pp. 319-338, InterVarsity Press, Downers Grove.

Sparks, K.L., 2008, 'The Song of Songs: Wisdom for Young Jewish Women', Catholic Biblical Quarterly 70(2), 277-299.

Strong, J., 2007, Strong's exhaustive concordance of the Bible, Hendrickson, Peabody.

Tichenor, V.J., 2005, Earning more and getting less: Why successful wives can't buy equality, Rutgers University Press, New Brunswick.

Tournier, P., 1969, To understand each other, transl. J.S. Gilmour, John Knox Press, Richmond.

Van Leeuwen, R.C., 2007, 'Cosmos, temple, house: Building and wisdom inMesopotamia and Israel', in R.J. Clifford (ed.), Wisdom literature in Mesopotamia and Israel, pp. 67-90, Society of Biblical Literature, Atlanta.

Waltke, B.K., 1979, 'The Book of Proverbs and Ancient Wisdom Literature', Bibliotheca Sacra 136(543), 221-238.

Waltke, B.K., 1988, 'Lady Wisdom as Mediatrix: An Exposition of Proverbs 1:20-33', Covenant Seminary Review 14(1), 1-15.

Walton, J.H. \& Hill, A.E., 2004, Old Testament today: A journey from original meaning to contemporary significance, Zondervan, Grand Rapids.

Wexler, B., 2003, Violent relationships: Battering and abuse among adults, Information Plus Reference Series, Thomson Gale, Detroit.

Whybray, R.N., 1972, The book of Proverbs, The University Press, Cambridge.

Whybray, R.N., 1990, Wealth and poverty in the book of Proverbs, JSOT Press, Sheffield. Whybray, R.N., 1994, Proverbs, William B. Eerdmans Publishing Co., Grand Rapids.

Worthington, E.L. (Jr), 1989, Marriage counseling: A Christian approach to counseling couples, InterVarsity Press, Downers Grove.

Wright, J.R. (ed.), 2005, Ancient Christian commentary on Scripture, Old Testament IX: Proverbs, Ecclesiastes, Song of Solomon, InterVarsity Press, Downers Grove.

Yoder, C.R., 2003, 'The Woman of Substance: A Socioeconomic Reading of Proverbs 31:10-31', Journal of Biblical Literature 122, 427-447. http://dx.doi.org/10.2307/ 3268385

Yoder, C.R., 2009, 'On the Threshold of Kingship: A Study of Agur (Proverbs 30)', Interpretation 63(3), 254-263. http://dx.doi.org/10.1177/002096430906300304 